\title{
Treatment of breast infection
}

The reference numbering went awry in this clinical review by J Michael Dixon and Lucy R Khan after a new reference was added at proof stage (BMJ 2011;342:d396, doi:10.1136/bmj. d396). The citation of reference 5 at the end of the legend to figure 1 in fact relates to reference 25 in the reference list at the end of the article (Hughes LE, Mansel RE, Webster DJT.

Miscellaneous conditions. In: Hughes LE, Mansel RE, Webster DJT, eds. Benign disorders and diseases of the breast: current concepts and clinical management. Edward Arnold, 2000:230).
And the references cited as 6 to 25 in the rest of the article relate in fact to references 5 to 24 in the reference list: each number in the text should therefore be reduced by one-for example, the citation of reference 6 in the opening sentence of "Which micro-organisms are implicated?" relates to reference 5 in the reference list (Moazzez et al. Arch Surg 2007;142:881-4), and so on.

Cite this as: $B M J 2011 ; 342: \mathrm{d} 3744$ 